\title{
Exile and Liminality:
}

Experience between Cultures and Identities ${ }^{1}$

\author{
EVA EGLĀJA-KRISTSONE
}

\begin{abstract}
To describe the exilic condition, many scholars have made use of the concept of liminality. Being neither here (Great Britain as a place of exile) nor there (Latvian exile society as a substitute of a nation) characterizes the life of one of the best Latvian existentialist prose writers - Guntis Zarinšs (1926-1965). In Zariņš life and work he negotiated several liminal areas - from his war and professional experience, literary presentation to his standing in the Latvian exile community. Whether it is voluntary/involuntary or internal/external, the process of exile is one where an individual is removed from a place of origin (a homeland) therefore one of the crucial questions to solve is a relationship between the experience of cultural displacement and the construction of cultural identity. The time when Guntis Zariņš became prominent in Latvian exile literature, coincided with the time when the change of generations had started. Guntis Zariņš was one of the first exile writers who visited Soviet Latvia in order to personally meet colleagues-writers from the other side of Iron Curtain and cooperate with them in the field of literature but he was trapped between two powers - Britain and Soviet secret services that eventually led to his mental instability and suicide. Zariňš' case is an example of an individual and undesired exile where prolonged liminal phase and inability to integrate neither into the host society nor to establish apolitical and cultural contacts with homeland resulted in an excellent existentialist prose on the one hand and ruined individuality on the other.
\end{abstract}

Keywords: exile, liminal generation, Guntis Zariņ̌̌, existentialism, Great Britain, Soviet Latvia

It is becoming increasingly clear that the nature and behaviour of thresholds constitute one of the thorniest and most exciting problems in textual and cultural studies. From post-colonial theory to sociology and anthropology, the concept of liminality has offered a means for understanding instances of cultural, social,

1 This work has been supported by the European Social Fund within the project "Cultures within a Culture: Politics and Poetics of Border Narratives”. (ESF 1DP/1.1.1.2.0/13/ APIA/VIAA/042)

DOI: http://dx.doi.org/10.12697/IL.2015.20.1.11 
and political "in-between-ness." Liminality interests those concerned with the study of borders, interstices, missing links; it is a dynamic concept associated with conflict, hybridity, blend, pollution; with chaos and creation; with fluidity of identity or of meaning; with the unstable or the unsettling; with transgression, subversion, or transcendence. And it is a sufficiently abstract concept for use in such disciplines as study ritual, culture and literature.

It is still important to speak about the large diaspora all over the world from the temporal and historical perspective, about intellectuals who after WWII were driven from their native realms and scattered around the world. Latvian emigree writers describe this constant state of deleriction in their fiction. For example, Guntis Zarinšs" account of the pulverization of subjects in exile: "These are figures for painting, but there is no background - who are we, where is our community? How shall I write about something that does not exist? Somewhere beneath the traditional definition there is an undercurrent - formed by people through art, architecture, laws, religion, philosophy and way of life. It is hard to see all these factors as united, but they are present to our feelings. We perceive human beings in groups that constitute community. We lack this undercurrent!" (Zariņš 1996: 180, italics in the original)

To describe the exilic condition, many scholars have made use of Victor Turner's concept of liminality (Turner 1969). Homi Bhabha states that the liminal is the place from which "the minority, the exilic, the marginal and the emergent" (Bhabha 1990: 300) may speak. Havid Naficy argues that any social group in exile is inevitably, a liminal one: "Exile is a process of perpetual becoming involving separation from home a period of liminality and in-between-ness that can be temporary or permanent (Naficy 1993: 8-9). The experience of a life that involves at least two cultures is an inseparable part of exile. Being neither here (Great Britain as a place of exile) nor there (Latvian exile society as a substitute of a nation) characterizes the life of one of the best Latvian existentialist prose writers - Guntis Zariñ̌s (1926-1965). The life story, which will be used as a central axis of the article, is not intended as a typical example of a Baltic exile that must serve as a generalisation. Nor should it be perceived as a story that is deeply rooted in the British environment and is conditioned by it, although each country of residence or displacement (Germany, Sweden, the USA, Great Britain, Australia and others) has its own peculiarities. It is a deeply individual and tragic story about the efforts of a creative person to settle down, cooperate and express himself in the environment where external socio-political events have brought him, about the feeling of in-between-ness and the threshold of unstable identities.

This is a case study of an individual in the 1950s and 1960s, who similarly to thousands of Latvians, had fled from his country before its occupation by 
the Soviet Union. At the same time it is a story, in which the typical outsiders' perspective of an exile looking at the new place of residence, inclination to the preservation of one's ethnic belonging and strong feelings for returning to homeland, quest for one's identity and struggle with post-war traumatic demons, as well as inability to get satisfaction at work and in social life might be noticed.

Guntis Zariņš was born in 1926 in Riga, he studied at Riga French Lyceum. In 1943, by forging his year of birth (telling that he was six years older), voluntary joined the Latvian legion in Vilis Janums' regiment, where he operated as an artillerist and completed the instructor's course. In 1944 after the battles in Jelgava he arrived in Pomerania, but at the end of the war in Berlin was taken as a prisoner by Americans. He later vividly revealed his wartime emotional experience in his novels and several short prose pieces (e.g. novel Varonības augstā dziesma (The Praise Song for Heroism, 1962)). After the release from captivity Guntis Zariņš was in various refugee camps in Germany and served in guard companies. He also managed to study philosophy at the Baltic University in Pineberg. In 1952 he immigrated to Great Britain, where at the time two options in terms of occupation were offered - a miner or a nurse. Guntis Zarinšs chose the work of a nurse. He studied at the nurse school, and since 1959 he had worked in the psychiatry ward. At the time his first prose book Dieva mērkakis (God's Monkey, 1959) was published. In 1953 Guntis Zariņš got married to Monika Zarina, his family lived rather remotely from the rest of the public, for some time not far from Stonehenge, but in 1962 he moved to Scotland. On the same year Guntis Zariņš visited America, thus fulfilling one of his dreams. Another dream was to visit Latvia and it happened - half a year before his death. After Scotland the family returned to London where in 1965 he committed a suicide.

While thinking about "exile" beyond the literal experience of emigration, as a form of "marginality" or "liminality" it always involves artistic and scientific endeavours. In Zarinšs life and work he negotiated several liminal areas - from his war and professional experience, literary presentation to his standing in the Latvian exile community. Firstly, it is crucial to look back to his wartime experience in a more detailed manner. In 1943 Guntis Zariņš started to serve in the Latvian legion and as he has put it: "I finished the war as a corporal, I was considered and awarded as a good soldier, but I hated each and every minute I had to spend in a battle. Not a single time I thought that I fought for Latvia, no - I was fighting for my own life.” (Gubina 1959) It was followed by a period in life that Guntis Zariņš hated, namely, - serving in numerous guard companies in Germany from 1948 till 1952. In these four years Guntis Zariņš did write one story and an article about Kafka in a German newspaper. He states that these were empty years full of hardship. 
Each big war has its so-called Lost Generation, which suffers proportionally biggest losses both in terms of the death rate and the disabled war veterans, and part of its participants "transform" over these war experiences - they cannot accept the beliefs, values and credos of the previous generations. Some scholars call this a "liminal generation", since the Lost Generation has already been used when referring to a group of $20^{\text {th }}$-century authors, who grew disillusioned after World War I. After World War II, this generation is also represented in war stories by Guntis Zarinšs. Finding oneself on the threshold between life and death, mud and blood, where mere accident and blind luck determined, who would remain with the living and who - with the dead, one finds it difficult to believe in a rational world order, and the power and constancy of social, ethical and God's laws. What remains is incredulity that taints the experience, as well as purely metaphysical feeling of loneliness, which Zariņ̌s is not excited about. On the contrary, he makes nearly all his characters fight with it, though mostly with no great success. In his works, Zarin, š attempts to solve the post-war problems that have occupied the minds of many Europeans. All Zariņš characters nearly with no exception are Latvians, Latvian emigrants or exiles, who live in the new environment and have no other choice but to look for a justification for their lives. Zariņš solves the problems that are characteristic for the entire epoch and thus are universal values related to the meaning of life and quest for one's identity. It must be noted that the post-war years were typical liminal space; a site of uncertainty and flux in which an entire generation felt as if caged in limbo.

In 1952 Zariņš left Germany to visit his sister and mother in England. It is interesting to read his reflections before and after coming to this country. Zarinšs, when writing about a Latvian poet, who moved to England, while he was residing in Germany, says that he did not have a clue what a poet can look for in a land that he visualised as factory chimneys wrapped in fog and cranes in docks and never thought that in this city of millions he would ever see at least one green leaf. Although in the beginning of the 1950s there was a viewpoint that London had become a European Mecco for Latvian cultural workers, due to the fact that many famous cultural workers had settled down there, Zariņš looked at this country very suspiciously in the beginning. Continuing with Zariņš description:

And so? Then I was thrown out in the station of the huge city - with two suitcases and a heart full of distrust. However, the first thing I saw was heaps of flowers, mostly roses. On each corner there were old women and men selling flowers. And when the double-decker was rocking me to the city outskirts, I saw that London and roses are two inseparable items. In front of each house there was a little garden and it was never short of one flower - a rose. It has 
been living on this island for several centuries and even the wars have been named after it. It sounds like a joke that during the war the Prime Minister Sir Winston Churchill in the darkest days of war reprimanded the Minister of Transport saying that there were not enough roses delivered to London. (Zariņš 1970)

London and England is one of liminal spaces and transitional place for Zariņš where he lacks social status and tries to define his new identity in this land. In normal circumstances, according to Zariņš, an individual obtains his or her identity in a group of society, where he or she belongs to. Yet, the question is how can the isolated exile individual find his or her ego and identity? In Zariņš opinion, it cannot be achieved easily. Perhaps, it only works in certain moments, when an individual establishes close relationship with another individual. Still, the lonely characters of Zarinšs often do not succeed, and then they die. As stated by exile literary scholar Juris Silenieks, "as an emotional state, exile cannot become endemic. Because of its initial intensity, it is likely to deteriorate fast. And only a lucid recognition of the fact that what is left of the incipient poignancy of shock and outrage is only perhaps a dull ache can rescue the committed writer from being trapped in the fixation of ideological orthodoxy and values that may turn out to be less than infallible and incorruptible." (Silenieks 1972)

Zariňš in his life and prose proves the assumption that exile is a liminal state. Whether it is voluntary/involuntary or internal/external, the process of exile is one where an individual is removed from a place of origin (a homeland). Once removed, the individual enters a period of liminality definitively between leaving one's origin and resituating oneself in a new place. Regardless of the length of the liminal period, it becomes an intrinsic characteristic of exile such that the exiled individual is unable to align him-/herself with a definitive state of belonging. In this way, the exilic status is in itself a location: neither here nor there (Marciniak 2006: 33). As Guntis Zarinš has noted about himself, his family and feelings in England: "There are only Englishmen around us, but in our rooms there is Latvia. Not the Latvia that we left behind, but the Latvia we still live in. I have many English friends, because we have a common spiritual world. I love Englishmen and England, the same way I love Germans and Germany, French and France, but I'm a Latvian!” (Gubin, 1959)

His liking and loyalty for England and maybe even try to integrate himself Zariņš has expressed both when informing about the political and social processes in the country in various Latvian newspapers, including the USA Latvian newspaper where he worked as a special correspondent, and his literary works. He was closely connected to the Rowfant House, which Latvian Lutheran Church in London started to lease from the Locker-Lampson family in 1953. 
Thanks to the voluntary work of its members, the house was made habitable again and was used for residential purposes and a variety of community events. Guntis Zarinšs considered popularisation of Latvian literature and culture in the countries of residence as his main task in exile. In an attempt to overcome the division caused by the Iron Curtain, Zariņš living in Great Britain, intended to establish an English-language publication in which works written outside and within Latvia would be published together. He took part in the foundation of a magazine "Zintis" dedicated to Latvian literature and published in English. Also, he established an international club at the Rowfant Estate near London where various literary and music events were held.

On the other hand, his cycle of short prose "London's Walks" reveals the feeling of great emptiness that is characteristic not only to London, but can be felt in places with large masses of people in general - as if people were running away trying to escape from themselves and their lives. This piece of prose offers an elaborate description of London streets and areas. Zariņš had well-studied Soho area, popular among famous artists, criminals, theatres and "professional lovers" - in his own expression. In this context, there is an episode worth mentioning. When a Latvian poet from Canada visited England, Guntis Zariņš accompanied her through London and the conversations, according to Zarin̦š, sounded like this:

Everything seems so weird to me, says the guest. The men wearing bowler hats and white carnations in buttonholes - the British clerks - seem so weird. Perhaps they look weird, indeed, but to me they seem so ordinary, and Americans in snug trousers and their trivial shiny cars seem weird... And here we are we have been separated by an ocean for seven years and different things seem weird to us. The royal postage carriage passes by and it also seems weird to the guest. To me - it's American president wearing the Indian headdress. (Zariňš 1959)

This shows the difference of two Latvian intellectuals who have the same roots but different places of exile. It also manifests the different cultures they live in and the environments, where they have to preserve their own culture. Thus, the problem of cultures within a culture and the question of minority and otherness are highlighted.

One of the crucial questions to solve is a relationship between the experience of cultural displacement and the construction of cultural identity. The time when Guntis Zariņš became prominent in Latvian exile literature, coincided with the time when the change of generations had started. Those who left Latvia as "the young ones", had become middle-aged, whereas the middle-aged 
generation had become old and young ones had been born. The young writers managed to obtain Latvian secondary education either in Latvia or in Germany, and they, having grown-up under the literary influence of both Latvian and another nation, had started writing without asking - how big their audiences would be like, if any at all. Assessing the opportunities of the writers of this young generation, conclusions were quite sad - who would ever read them? Because in exile there were writers who had gained some recognisability in Latvia, and they were being read. So, it turned out, that this "lost generation" was writing for its own sake. They read themselves and fully understood but it was hard for them to find audience outside their generation. And the lack of reader and soul mates is a really typical explanation in the case of Zariņš, too. He felt lonely in his generation and creativity in Great Britain, therefore his dream was to visit the USA and Latvia and to see the writers of his generation, whom he had felt as his confederates since the 1950s. It is significant that Guntis Zariņš did not belong to any of the numerous Latvian exile organisations and was only a member of the PEN club, because, according to Zariňš, writers must be completely independent and unaffected by public views.

With the dissipation of hope for an early return to Latvia and with further emigration to more distant lands, new thematic shifts took hold, indicating awareness of the new environment. Zarinšs' feelings were manifested in the statement that he lived between the Thames and the Daugava river, because he had fallen in love with England, but he loved Latvia as a homeland. Zariņš explains that English Latvians use the words "us" and "you", where "us" referred to English Latvians, but "you" to Latvian Latvians, in order to demonstrate that in the exile country they were subconsciously aware of the fact they were situated outside the Latvian society and that in general exiles were situated outside society and this is a sense of marginalization. The trope of exile is that it is composed of both placement and displacement. The exile is expelled from one place (a homeland, a place of origin, a nation with its own identity) and undergoes a process of realignment into a new nation (the host land with its own separate identity).

Guntis Zarinšs is the most prominent author of Latvian existentialist prose. In his novels Apsūdzèts (Accused), Dvēseļu bojā eja (The Death of Spirits) and short stories, the dominating themes reveal the influence of the French existentialists. As stated by one of Zariņš’ contemporaries, Roberts Mūks, also a poet and philosopher, "No one can ban Guntis Zariņš from being Latvian sartrist or the like. It gives rise to a change in our emigration prose texts, in which so far great efforts have been pursued to overlook the most outstanding Western movements in the spiritual life of the West as presumably damaging the Latvian spirit." (Mūks 1962: 119) Zarinšs tried to write about the subjects chosen by well-known existentialists, beginning with Kierkegaard, Camus, Sartre, Heidegger, Jaspers, 
Proust and Kafka. The young writer named Joyce, Kafka, Hermann Hesse, Thomas Mann, Christopher Marlow and Gabriel Marcel as his most favourite authors. In the first compilation God's Monkey the thematic scope ranged from war to the occupied Latvia and a life in exile. However, the emphasis was laid on the emotional experiences of a sensitive individual, the spiritual loneliness of an exile and inability to settle down and adapt to the daily life of a foreign country, alienation and despair. Consequently, Zarinšs prose works are intertwined by tragic feelings of exile, severe pain about isolation from Latvia and his people, as well as desperate quest for national identity and his own identity.

As it was already mentioned before, having arrived in England, Zariņš started to work and study in one of the biggest hospitals of England as a registered mental nurse. Guntis Zarinšs graduated from the nurse school and worked in the psychoanalytical hospital with children. In the beginning he looked at it as a very positive job. However, already in 1959 some Latvian poet indicate that the breadwinning job has left some footprint on the literary work of G. Zariņš that can be noticed, for example, in the article published in London Newspaper about the mental illness ${ }^{2}$ and its symptoms in the works of English writer Thomas De Quincey ${ }^{3}$. And this article was only the beginning for a bigger series that was planned and would include articles on poet Christopher Smart and essayist Charles Lamb, as well as Carl Swinburn, John Keats and Balzac.

An exile belongs to neither state; his or her placement is defined by displacement from a place of origin or homeland. Guntis Zariňš and his wife Monika Zarina were the first exile writers - they were even called Trojan horses - who visited Soviet Latvia in order to personally meet colleagues-writers from the other side of Iron Curtain and cooperate with them in the field of literature. ${ }^{4}$ Zarin, visited Latvia in 1964 together with sons, whereas Zariñš - in March 1965 (the trip planned in November 1964 did not take place because his visa was rejected in Moscow). Following the invite from the Cultural Relations Committee of the KGB, G.Zariňš arrived in Riga with a suitcase full of books and eager to establish contacts and publish a joint literary magazine. By showing

2 In the beginning of the 1960s Zariņš also wrote "A Manual for Mentally Ill Children Carers", because he himself had worked in this field for ten years and had obtained such a big experience that he could transfer his knowledge to others. The manuscript in English was finished, but there is no evidence that it was also published.

3 an English essayist, best known for his Confessions of an English Opium-Eater (1821). Many scholars suggest that in publishing this work De Quincey inaugurated the tradition of addiction literature in the Wes

4 This case is analysed in Eglāja-Kristsone 2013. 
initiative to publish an almanac of Latvian literature and art in English language, compiling artistically high-valued works of exile and Latvian SSR writers and artists, Zariņš aroused interest not only on the Soviet Latvian side, but also on the British side, who were willing to support his cultural relations with a purpose to ideologically influence the Soviet public. In a letter written in 1964 to poet Gunars Saliņš living in the USA, Zariņš confidentially explains: "[...] the English attitude is the following: the bigger contact we have with them, the greater the chances that we will be able to liberalise them, and the liberalisation of Communism is the end of Communism. [...] At the moment the situation is the following - they need me as a "deserter" and the symbol of a liberal - communist emigrant." (Ceplis 2001: 1976) The tragedy of this symbolic journey has to be explained from two aspects. First, Zariņš might felt like trapped between two powers - Britain and Soviet secret services that eventually led to the second aspect -an exacerbation of his mental instability and alcoholism. It turned out his dreams were naïve and reality was too harsh, Zarinš understood he was only a weak gambler in the game of two powers.

English newspaper Tooting and Balham Gazette issued on 17 September on the first page under the title "Upper Tooting Hanging Tragedy" provided an article about the sudden death of Zarinšs, indicating that the 39 years old Latvian writer, who worked as a carer, periodically suffered from depression. His wife Monika indicated that from time to time he also used alcohol in abusive amounts and had tried to commit suicide two more times before - first, with sleeping pills, but in May the same year by a hanging attempt. Guntis Zariņš had also been treated at a mental hospital. On the day of tragedy Zariņš' mother-in-law Marija Majora, according to the British newspapers, visited him, but finding the bedroom's door locked thought that he was still asleep. Only later, when Zariņš oldest son returned from school, the tragedy came to light. Doctor Robert Teer stated that Zarinš had committed suicide by hanging himself and that at the moment of death Zarinš was under a heavy influence of alcohol. Guntis Zariňš was buried in Latvian section of Brookwood cemetery in London. Exile Latvian newspapers actively discussed this tragedy and its reasons. One part of the public thought that suicide was imitated by the special units of one or the other country, another thought that the intention to establish close contacts and cooperation with the Soviet Latvia was naivety and an unfair game from the Soviet side.

As Dawson and Johnson (2001: 330) have pointed out, the classical conception of liminality as a particular though temporary state or phase existing between movement from one fixed state or place to another is perhaps not the best or most subtle way to conceptualise marginality. This view of liminality, they argue, merely affirms the fixity of the 'states of being' that it is presumed to 
lie between, rather than acknowledging the continually fluid and mutable nature of identity. In a world that wants to control and classify its relationships with all individuals and groups the exile is perhaps most frightening, because exiles occupy that liminal space that defies any category. Zarinšs' case is an example of such most frightening destinies of an individual and undesired exile where prolonged liminal phase and inability to integrate neither into the host society nor to establish apolitical and cultural contacts with homeland resulted in an excellent existentialist prose on the one hand and ruined individuality on the other.

\author{
Eva Eglāja-Kristsone \\ Eva.eglaja@lulfmi.lv \\ LU Literatūras, folkloras un mākslas institūts \\ Mūkusalas iela 3 \\ LV-1423 Rìga \\ LATVIJA
}

\title{
Bibliography
}

Bhabha, H. 1990. DissemiNation: time, narrative, and the margins of the modern nation. - H. Bhabha, ed., Nation and Narration. London: Routledge: 291-322.

Ceplis, R. 2001. Uz naža asmens. Viena tauta. Iz kultūras sakaru vēstures. - Karogs, 2, 172-177.

Dawson, A., Johnson, M. 2001. Migration, exile and landscapes of the imagination. B. Bender, M. Winer, eds., Contested landscapes. Oxford: Berg, 319-332.

Eglāja-Kristsone, E. 2013. Dzelzsgriezēji. Latvijas un Rietumu trimdas rakstnieku kontakti. Riga: LULFMI. [Iron Cutters: Contacts between Latvian and exile writers, contains an abstract in English.]

Gubiņa, I. 1959. Guntis Zariņš. - Tilts, 36-37, 24-25.

Marciniak, K. 2006. Immigrant Rage: Alienhood, “Hygienic” Identities, and the Second World. - differences, 17 (2), 33-63.

Mūks, R. 1962. Apsūdzēts...? - Jaunā Gaita, 36, 119.

Naficy, H. 1993. The making of exile cultures: Iranian television in Los Angeles. Minneapolis: University of Minnesota Press.

Silenieks, J. 1972. Latvian literature in exile: the recycling of signs. - Lituanus, 18, 13-17.

Turner, V. 1969. Liminality and communitas. - The ritual process: Structure and antistructure. Chicago: Aldine Pub. Co, 94-130.

Zariņš, G.1996. Trimdas mìts. - Karogs, 8, 176-184.

Zariņš, G. 1970. Londonas pastaigas. - Tilts, 2, 59-98.

Zariņš, G. 1959. Kanadas viešņa Londonā. - Latvija Amerikā, 17.07. 